Spring 1994

\title{
What Every Professor Should Know About Cheating in the Classroom
}

Peter M. Edelstein

Follow this and additional works at: https://digitalcommons.fairfield.edu/nealsb

\section{Recommended Citation}

Edelstein, Peter M. (1994) "What Every Professor Should Know About Cheating in the Classroom," North East Journal of Legal Studies: Vol. 2 , Article 2.

Available at: https://digitalcommons.fairfield.edu/nealsb/vol2/iss1/2

This item has been accepted for inclusion in DigitalCommons@Fairfield by an authorized administrator of DigitalCommons@Fairfield. It is brought to you by DigitalCommons@Fairfield with permission from the rightsholder(s) and is protected by copyright and/or related rights. You are free to use this item in any way that is permitted by the copyright and related rights legislation that applies to your use. For other uses, you need to obtain permission from the rights-holder(s) directly, unless additional rights are indicated by a Creative Commons license in the record and/or on the work itself. For more information, please contact digitalcommons@fairfield.edu. 
WHAT EVERY PROFESSOR SHOULD KNOW ABOUT CHEATING IN THE CLASSROOM*

by

Peter M. Edelstein*

\section{INTRODUCTION}

Typically colleges and universities inform students and prospective students of the institution's standards of academic integrity. This is usually accomplished by a notice in the institution's catalogue or related materials. ${ }^{1}$ The notice language should be broad enough to proscribe all forms of cheating. Students should be expected to understand that unethical conduct would include copying from any source without proper attribution, looking at another's answers during an exam, communicating with another during an exam, bringing information into the exam room (or placing it in the exam room prior to the exam), collusion with another on an assignment, or presenting another's work (including purchased papers) as one's own. Yet a recent survey of undergraduate students in one form or another while in college.

All forms of unacceptable academic conduct, from plagiarism to the use of "cheat sheets" during an exam, are not only violations of the precepts set forth in the University catalogue but are an insult to the entire academic process and especially to those individuals who do adhere to the principles of academic integrity. At many institutions, the functions of policing adherence to the academic honesty standards and of administration of justice in the event of a violation or alleged violation thereof, have been bestowed primarily and initially upon the faculty. This paper is intended to assist instructors in understanding and addressing their functions.

* Copyright 1993, Peter M. Edelstein.

* *Professor of Law, Pace University, Lubin School of Business.
FORMS OF CHEATING

All forms of academic dishonesty involve either the wrongful act of using another's knowledge as one's own or using one's own knowledge in a wrongful manner. Copying without attribution, using other student's work product, buying a commercially available term paper, are examples of the use of another's knowledge. Using "cheat sheets" or using other information surreptitiously during The lint of method of cheating is limited only by the imagination of the students.

In response to a request for methods of and devices for cheating, the following list was generated by students in the cheating, the 4

- During the semester and particularly shortly before the exam write information on the desk. Pencil works best because it can be rubbed of $f$ th the end of the exam.

- A chart or a page of text from a textbook can be photocopied and then repeatedly reduced by the copier to the size of matchbook and brought into the exam room.

- If the instructor has informed the students in advance of the questions or gives the same exam to all sections, before the exam write the answers in a blank exam booklet, dispose of its colored cover, bring the pages into the exam room and at the opportune time remove the interior pages from the exam book distributed by the instructor, retain its colored cover and make a switch. Tell the instructor, the "staples came out".

- Bring a calculator into the exam room and insert answers between the device and its case.

- Bring a calculator or "spell check" device into the exam room which will accept words or symbols that cue the correct answers.

- Arrange a code system with another student to convey answers using body language; for example, hand opened or closed for true or false; count the fingers for multiple choice.

Go to the restroom with concealed information.

- Install information in the barrel of a ball point pen.

- Use the same or a similar paper for assignments in several courses; it can be yours or that of another.

- Drop things on the floor (pencil, paper); look at concealed 
information.

- Do not attend the regularly scheduled exam, then debrief a friend who took it; request a make-up due to illness.

- If in a large class, do not attend the exam; when the grades are given or the exam returned, tell the instructor that you didn't receive yours. Accept the instructor's apology and negotiate a method to replace the missing grade (after you have debriefed a friend).

- Arrange for one student to distract the instructor while nother student looks at helpful information or the answers of another.

While no list of acts of academic dishonesty can ever be complete, an awareness of some of the means and variations of this type of behavior enhances the ability of an instructor

III

THE ROLE OF THE INSTRUCTOR

As instructors we embrace and endorse the concept of teaching ere is little debate on the erits of ind our curriculum, but we 作 ethics. If the two concepts are, in fact, related perhaps we should devote a relatively proportionate amount of attention to the requirements of academic ethics.

Demanding academic honesty of our students requires multiple missions of instructors: teaching, policing, preventing and enforcing. We are not expected to be experts in surveillance and to be enablers.

Consider the following practices:

- At the beginning of each course announce or give the students notice of your policy concerning academic integrity. Relate academic honesty to business ethics. Give examples of wrongful practices. Explain the sanctions attendant to the wrongful acts. Reinforce the message at appropriate intervals.

- Before an exam look at the writing on the desks.

- Before the exam announce that no pages are to be ripped from exam books and that no exam book covers are to be detached.
- Use different color exam books for each exam.

Seat students randomly for an exam, not in their usual assigned seats.

- During the exam, walk the aisles frequently, look at what is on the floor and on the desks.

- If a student has a question during the exam, request that he or she comes to you with his or her exam and booklets. Do not go to the student's desk, hunch over and turn your back to the rest of the class.

- Inform the students that nothing is permitted on the desk during an exam; books and belongings go under their seats (not under the table part of the desk or in the aisles where they can be seen).

- While there is a difference of opinion as to whether the instructor should sit in the front or rear of the exam room, sit where you can observe the whole room.

- Use different exam for each section. Vary the exams from semester to semester.5

IV

THE SOURCES OF STUDENTS' RIGHTS

In the event an instructor believes a student has cheated, care must be taken, both procedurally and substantively in handling resolution of the matter. If the instructor and the institution are not attentive to the rights of the student, the courts may be called upon by the student to intercede on his or her behalf. There are two basic sources of students rights upon which a court will rely when intervening in the student-university the United States, and (ii) a theory of contract law.

The fourteenth amendment states in relevant part: "No state shall make or enforce any law which shall abridge the privileges or immunities of the citizens of the United States; nor shall any state deprive any person of life, liberty, of property, without due process of law..." This language, commonly referred to as the "due process clause" has been held to be applicable to protect one only from state action and, therefore, in the context of a student attending a college or university, the actual due process protections are only available to those attending a state or public university. There have been many cases concerning the issue of whether a particular college or university is to be considered public or private for purposes of the application of the due process clause. In many instances it is obvious that the private institutions may be deemed to be state or public due to 
factors such as their tax exempt status, receipt of federal funds, receipt of state funds, exempt status under state and local law, or public function interest. If in doubt about the legal status sult with an appropriate member of the administration or the institution's counsel.

At public universities, the fourteenth amendsent is applicable to the area of acadenic discipline because it has long been held that a student has a property interest in education and any possible denigration of a student's good name, reputation, honor or integrity may involve a liberty interest.

Private college students derive their rights primarily from a theory of contract law which holds that an implied contract is deemed to exist between a university and its students. By the terms of this contract, the student is deened to agree to pay the required the un and to abide by the divery awer the appropriate degree upon the successful conpletion of the con or violates the contract and as a result may not be entitled to receive the dentract 13 and as a ro university catalogue and in its other publications. ${ }_{14}$ in the university catalogue and in its the school's standards would be considered binding by implication upon the students, 15 and the obligation to accommodate the students' reasonable expectations in awarding the degree would be deemed binding on the school.

$\mathrm{V}$

RIGHTS OF STUDENTS

Public university students, by relying on the due process clause, and private university students (unable to assert rights under the due process clause), by relying on the contract theory, have achieved similar protections when challenging university decisions that were allegedly "arbitrary" or "capricious" or "irrational" or "made in bad faith."

The courts, in private school cases, while embracing the contract theory on one hand make it known on the other that the student-university relationship is a special one and, therefore, two results follow: (i) the courts do not rigidly apply the rules of commercial contract law, and (ii) the courts are most reluctant by the institution, without interference from the courts. Thi combination of a rejection of a rigid application of commercial contract law and reluctance to intervene in acadenic decisions has resulted in an historical legal environment especially favorable to college and universities that allows substantial latitude in their decisions and in the process of administration of justice to students. 22
The principal rights afforded students at a private institution are a function of the doctrine of "reasonable expectations." This doctrine is used to determine the meaning college or university would reasonably expect a student to attribute to the terms of the contract. Since there is little reason for private university students to perceive that they should be afforded lesser or different rights than public or state university students, they can reasonably expect to be afforded the ame general rights and protections available to public or state

Thus, using public universities as a model, private school students can reasonably expect to benefit from the same rights a public school students: fair notice of their alleged misconduct an an opportunity to be heard in a process appropriate to the nature fre due process) while there is aspects of the academic process 27 based on a reluctance to int upon the discretion afforded institutions in matters of student affairs 28 the University will be vulnerable to legal action if it does not offer its students certain legal accommodations.

VI

SUGGESTIONS FOR AFFORDING STUDENTS THEIR RIGHTS

The following suggestions are offered as a means of complying with the

- In the event of a perceived act of cheating during an exam, the faculty nember may elect to take immediate action ranging from a whispered warning to the student, to moving his or her seat, to confiscation of the paper. In any event, do not overtly embarrass or humiliate the student or accuse him or her of wrongful conduct in front of the other students. Such acts may constitute defamation (if the student was, in fact not cheazting) or the intentional infliction of emotional distress (even if the student was cheating). Do not touch the student. Touching may be considered assault, battery or sexual harassment.

If you elect not to confront the student during the exam, make notes of the detalls of the incident: time of day; where the student was sitting; suspicious activity and other relevant facts. In the event the matter is not thereafter immediately resolved, this information will be important to refresh your memory of the incident in the event a hearing or litigation takes place weeks or months later.

If you elect to address the situation after the exam or if the wrongful act took place out of the exam environment, speak to the student privately, promptly after your observation, and 
inform the student of your conclusions and sanctions. If the student and you are willing and able to resolve the matter at the student-instructor level, do it. Expenditures of time, effort, emotions and cost increase in proportion to the duration of the process. Every effort should be made to resolve the matter between the instructor and the student. If the student contests your observation or objects to the nature or severity of the sanction or if you feel the matter cannot be resolved at the student-instructor level, administration of the university becomes involved.

- The university should have adopted written procedures for handling matters involving academic dishonesty and should in adhere to those procedures and apply them

consistently. ${ }^{34}$ If you do not believe that the matter can be handled at the student-instructor level, an appropriate representative of the university should inform the student in witing of the charges and the sanctions you imposed and and the student that he or she has the right to a hearing process by inforing the chairperson the chajuren or other presignated student in writing of the details of the appeals procedure. By notifying the student of the details of his or her right to appeal the instructor's decision the school is not only affording the student rights that may be required by law but the availability of the appeal process may serve law, but the matter from escalating from academic environment to a legal environment.

- The hearing should be held before an impartial panel which may consist of a mix of, or exclusively of, representatives of the faculty, administration and/or student body. The hearing should be conducted in an orderly fashion with the student, the instructor and others involved having a reasonable opportunity to be heard. There are no requirements that legal rules of evidence or the formality of courtroom procedures be followed. ${ }^{35}$ The instructor should attend the hearing and be prepared to fully inform the student of the observations that led to the conclusion of wrongdoing and to justify the sanctions imposed. The student should be permitted to bring a representative if he or she so chooses, and the student and the representative should be allowed access to all available evidence. The student and his or her representative should be given the opportunity to question the instructor and any witnesses. If the student elects to have a lawyer serve as his or her representative, prudence would dictate that the University do the same. Minutes should be taken and retained. When the hearing is concluded, the decision-making panel should within a reasonable time inform the student in writing of its decision.

- All parts of the proceeding should be kept confidential. It is not necessary nor advisable to have a succession of appeals procedures to different or "higher" bodies or boards. ${ }^{36}$

- If in doubt about the nature or legality of an action to be taken in any particular case, consult with your chairperson who will have access to the institution's counsel.

- To the extent possible the school should treat cheating as an academic matter, rather than as a disciplinary matter, to in academic affairs.

VII

LEGAL AND ECONOMIC RISKS OF THE INSTRUCTOR

It is not difficult to imagine that, in some cases, issues of acadenic dishonesty will necessarily move from the classroom to the courtroom. Litigation, in any form, is expensive and coting regardless of your legal position. If you are required to defend your observations, sanctions, conduct or reputation, who will pay the costs?

Many institutions have a policy (or contract provision) providing for indemnification of faculty against the reasonable expenses, including attorneys' fees, actually and necessarily incurred in connection with the defense or appeal of certain law suits. Check with your school to assure that such protections are available to you.

$$
\text { VIII }
$$

\section{CONCLISION}

Academic integrity will be an issue as long as there are students competing for grades, graduation and jobs. By being aware of the various forms of academic misconduct and doing our part to enlighten our students in matters of integrity and ethics, perhaps we will deter such misconduct while fulfilling an obligation to the ethos of our profession.

The process of policing adherence to the school's standards and of administering justice is initially in the hands of th take all steps to afford them the appropriate procedural and substantive protections to which they are entitled.

\section{$\star \star \star$}

ENDNOTES

1. Four sentences in the Pace University Undergraduate Catalogue serve as a notice to students of the University's expectations concerning academic integrity: "students must accept the 
responsibility to be honest and to respect ethical standards in meeting their academic assignments and requirements. Integrity in the academic life requires that student demonstrate intellectual and acadenic of all assistance except that authorized by the instructor. The use of an outside soure in anyt the appropriate subision acke's own work, the ideas, words or representations of another without the proper indication of the source. Therefore, it is whout ls the sor an outside source." Pace University Undergraduate Catalogue, 1992-1993, p. 72.

2. Survey conducted in one section each of the author's Law 101, 212 and 213 classes on February 1,1993 , February 4,1993 and this anecdotal exercise have my gratitude for their

candor. See Appendix "A" for sample questionnaire.

3. Some institutions of higher learning have adopted the "honor system" by which the students assume primary responsibility for their honesty and agree to report any violation of the honor code. Princeton, for example, gives jurisdiction over all written exams and tests to the Undergraduate Honors comittee which operates on the honor system. Jurisdiction over all other academic work, including essays, term papers etc., resides with the Faculty-student committee on Discipline.

4. Some of the rethods and devices were included in the responses to the survey referred to in note 2 . above. Others were told to the author "off the record".

5. I have yet to learn of a meaningful deterrent to the student who "really has to go" to the restroom.

6. U.S. Const, amend. XIV, $\$ 1$.

7. See Civil Rights Cases, 109 U.S. 3 (1883).

8. Dixon V. Alabama state Board of Education, $294 \mathrm{~F}$. 2 d 150 (5th Cir. 1961).

9. See, for example: Grafton V. Brooklyn Law School, 478 F. 2d 1137 (2d Cir. 1973), re tax exempt status; Weise v. Syracuse University, 522 F. $2 \mathrm{~d} 397,404$ (2d Cir. 1975), Wahba V. New rork University, 492 F. 2d 96, 103 (2d Cir. 1974) B Berrios . Inter American University, 535 po $2 \mathrm{~d}$ 1930, 134 (7th 1976 Cannon v. University of chicago, 1559 (7th cir. 1977) trevid on other groundsit 556,562 (D.C. Cir.) cert. den. 423 U.S. 995 (1975), Blackburn v. Fisk University, 443 F. 2d 121, 123 (6th Cir. 1971), Browns V. Mitchell, $409 \mathrm{~F} .2 \mathrm{~d} \mathrm{593,} 595$ (10th Cir. 1969), Grossner V. Trustees of Columbia University, 287 . (S.D.N.Y. 1968), re receipt of Federal funds; Cannon V. University of Chicago, 559. $2 \mathrm{~d}$ 1063) (7th cir. 1977), Powe

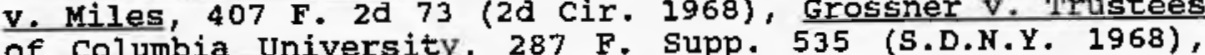
of Columbia university, 287 . Berrios V. Inter American college, $440 \mathrm{~F}$. Supp. 464 (D. Mass. 1976), Lorentzen $v$. Boston college, 440 Shast 1977), re receipt of state fund (S.D.N.Y. 1976), re tax exempt status under state and local law; Krohn v. Harvard Law School, 552 F. 2d 21, 24 (7th Cir. 1977), Grossner V. Trustees of Columbia University, $287 \mathrm{~F}$. Supp. 535,547 (S.D.N.Y. 1968), Cohen V. Illinois Institute of Technology, 522 F. $2 d$ at p. 404, n.6., re public function interest.

10. Dixon V. Alabama State Bd. of Educ., 294 F. $2 d 150$ (5th Cir. 1959); cert. den., 368 U.S. 930 (1961).

11. Wisconsin v. Constantineau, 400 U.s. 433, 91 s. Ct. 507 (1971); Board of Regents v. Roth, 408 U.S. 564 (1972).

12. See Carr V. St. Johns, 17 A.D. $2 d 632,633$, N.Y.S. 2d 410, 413 (1962), Slaughter V. Brigham Young Univ., 514 F. $2 d 622$ 423 U.S. $898(1975)$.

13. See Anthony v. Syracuse Univ., 224 A.D. 487, 231 N.Y.S. 435 (1928).

14. See Andersen V. Regents of Univ. of Cal., $22 \mathrm{Cal}$. App. 30 763, $99 \mathrm{Cal}$. Reptr, 531 (1972), Johnson v. Lincoln Christian College, 150 Ill. APP. 3d 733, 501 N.E. 2d 1380 (1986), Behrend v. State, 55 ohio App. 2d 135, 379 N.E. $2 d 617$ (1977), Drucker v. New York University, 57 Misc. $2 d 937,293$ N.Y.s. 2d 923 (Civ. Ct. 1968) rev'd. 59 Misc. 2d 789, Jo0 N.Y.S. 2 749 term 1969) aff'd. 33 A.D. 2d 1106, 308 N.Y.S. $2 d 644$ (1970), Goldstein v. New York. University, 76 App. Div. 80 (1902):

15. Students may be bound if they knew or should have known of the rules. See slaughter v. Brigham, $514 \mathrm{~F}$. 2d 662 .

16. See Giles V. Howard Univ., 428 F. Supp. 603 (1977).

17. Connelly v. Univ, of Vermont, 244 F. Supp. 156 (D. Vt. 1965) See: "Contract Law and the Student-University Relationship". 48 Ind. L.J. 253 (1972-1973).

18. See: Latourette and King, "Judicial Intervention in the student-University Relationship: Due process and contract Student-University Relationship: Due Process and Contract of Detroit Law Review 199-258, (January, 1988). 
19. Slaughter V. Brigham Young University, 514 F. 2d 622, at 626: "The student-university relationship is unique..."

20. Id.

21. Board of Curators V. Horowitz, 435 U.S. 78 (1978), Depperman V. Univ. of Ky., 371 F. Supp. 73 (E.D. Ky. 1974).

22. See "Judicial Intervention in Expulsions or Suspensions by Private Universities", 5 hilliamette L.J. 277, 280 (1968-
1969).

23. Giles V. Howard Univ. 428 F. Supp. 603 (D.D.C. 1977).

24. See "Contract Law and the Student-University Relationship", 48 Ind. L.J. 253, $266(1972-1973)$.

25. Ross v. Pennsylvania State Univ., 445 F. Supp, 147, I53 (M.D. Pa. 1978), citing Goss v. Lapez, 419 U.S. 565, 95 s. Ct. 729 (1975).

26. See Gaspar V. Burton, 513 F. 2d 843 (10th Cir. 1975); Aubuchon V. Olsen, 467 F. Supp. 568 (E,D. Mo. 1979): Depperman U. Univ of KY 371 F. Supp 73 (E.D. KY 1974) i Connelly Jniv of Vt 244 . 282 Ala. 358, 211 So. 2 d 489, cert. den.; 393 U.S. 939 (1968),

27. See Latourette, 200-201. See also Healy V. James, 408 U.S. 169,92 s. Ct. 2338 (1972).

28. Id.

29. Defamation is an injury to the person and to one's reputation-- that is, to one's right to enjoy the good opinions of others. New York Jur, Defamation and Privacy, \$1.

30. New York expressly recognizes the independent tort of intentional infliction of emotional distress. A person may be liable for conduct which is extreme and outrageous and causes severe emotional distress in another. New York Jur, Fright, Shock, and Mental Disturbance, $\$ 2$.

31. An assault is an intentional attempt displayed by violence or threatening gesture to do injury to, or commit a battery upon, the person of another. New York Jur, Assault - Civil Aspects, §1.

32. Battery is the intentional and wrongful physical contact with the person of another without the other's consent. A touching can constitute a battery if done in a rude, angry or insolent manner. New York Jur, Assault - Civil Aspects, \$1.
33. Sexual harassment is defined in the Pace University pamphlet as "...an attempt to coerce an unwilling sexual relationship, or to subject a person to unwanted sexual attention, or to punish a refusal to comply or to create a sexually intimidating, hostile, or of ensive working or educational environment. Sexual behavior includes a wide range of behaviors, from the actual coercing of sexual relations to the unwelcome emphasizing of sexual activity, verbal harassment or abuse, unicols The definition will be applied consistent with accepted

34. Tedeschi v. Wagner college, 49 N.Y. 2d $652,1980$.

35. See Board of Curators of the Univ. of Missouri $v$. Horowitz 435 U.S. 78 and Goss v. Lopez, 419 U.S. 565 (1975).

36. See Board of Curators v, Horowitz, 435 U.S. 78 (1978) Gaspar_v. Burton, 513 F. 2d 843 (1975). 